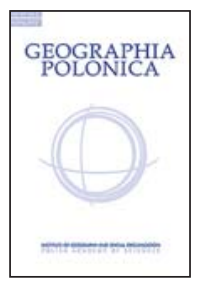

\title{
CAN A PANDEMIC STOP OR SLOW THE ANTHROPOCENE?
}

\section{Marek Więckowski}

Institute of Geography and Spatial Organization

Polish Academy of Sciences

Twarda 51/55, 00-818 Warsaw: Poland

e-mail: marekw@twarda.pan.pl

\begin{abstract}
The entire Earth system consists of fully dynamic conditions. Humankind's manifold large and small influences on the planet are now very well-documented. Changes are so vast, their traces so significant, that we have come to term this as if it was genuinely a new Epoch in the history - as the Anthropocene. Recently, however, the COVID-19 pandemic has shown us how an ostensibly small event at a single locality can take just a few weeks or months to change the world, and in some real sense to stop it. The author in this article in particular seeks to inject a further dose of far-reaching reflection on our pandemic, its influence on life on Earth, and its possible future consequences. Ultimately, then, it seeks an answer for a key question - as to whether COVID-19 is really in a position to stop, or at least slow, the runaway Anthropocene. With a view to encouraging reflection on humankind's potentially reduced impact on the planet the Author suggests priority areas of study in the near future.
\end{abstract}

\section{Key words}

Geography • Anthropocene • pandemic • COVID-19 • IGU • globalisation

\section{Introduction}

Human beings have come to dominate one planet in the Solar System, and have tangled it up with extensive and powerful linkages on many levels. White patches on the map have been erased, virtually every corner of the Earth has been visited, and there are hardly
"We do not inherit the Earth from our ancestors: we borrow it from our children."

Antoine de Saint Exupery 
unpredictable, showing how an apparently minor event here can give rise to perturbations somewhere else, and in quite different spheres of life or human endeavour, and even in nature.

We have been building a weapon of mass destruction whose use has irreversible consequences. We provoke conflicts whose local foci may transform into global cataclysms. Mobility and globalisation have pushed their way into every home and are exerting influence on our lives. The spread of ICT and digitisation have ensured that all can be instant and abrupt, whether that be information, knowledge, events, flows of funding, or economic decisions. So people have now modified their planet so far - and left such an indelible impression on it - that some of them have now started to make use of the term Anthropocene for the Epoch through which we are living. By definition, resort to the word Anthropocene defines Earth's most recent geological time period as human-influenced.

In the last few decades we have managed to limit hunger, disease and war to a considerable degree and, while these problems are obviously not resolved in full, we have at least started to treat them as challenges or obstacles that are out there to be tackled (Harari, 2015: 8). Recently, however, the COVID-19 pandemic has shown us how an ostensibly small event at a single locality can take just a few weeks or months to change the world, and in some real sense to stop it. As Tooze (2020) put it: "The Covid-19 economic emergency of 2020 is the result of a massive global effort to contain an unknown and lethal disease. It is both a surprising demonstration of our collective power to stop the economy and a shocking reminder that our control of nature, on which modern life rests, is more fragile than we like to think. What we are living through is the first economic crisis of the Anthropocene".

For several decades now, Geographia Polonica has been presenting the world from the geographical point of view, publishing articles on our planet's spatial differentiation, and laying emphasis on events, impacts and dependent relationships pertaining in Polish and European space. And, as IGU regional conferences and congresses have come and gone in their more or less organised cycles, we have every now and then made special editions ready - against the background of the many and varied matters crucial for planet Earth that geographers are able to address. 2020 was to have brought a Congress in Istanbul focusing in on Geography: Bridging the Continents. Its main listed topics are: Globalisation vs Localisation, Climate change, Migration and conflicts, Earth disasters, Eurasia and Middle East studies and the Anthropocene (IGC, 2020).

As the organisers of the Congress emphasise, while simultaneously invoking a classic definition: "Geography is the science of the relationship between the Earth and the human being". But Geography is not only such a science, since it also encompasses input of the evaluation, interpretation, awareness and analysis kinds. This could well be regarded as promoting geography to the lofty status of "Queen of all sciences" (IGC, 2020).

Given the occasion, we sought to prepare a Special Edition. And, notwithstanding all the problems, and hence the Congress' postponement to 2021, we have decided to go ahead with publication. Naturally, though, COVID-19 as the cause of that change - as of so very, very many other changes - has imparted a new outlook on the world. This volume is therefore remodelled quite a bit in comparison with what was originally foreseen for it. In line with that fact, the author in this article in particular seeks to inject a further dose of far-reaching reflection on our pandemic, its influence on life on Earth, and its possible future consequences. Ultimately, then, it seeks an answer for a key question - as to whether COVID-19 is really in a position to stop, or at least slow, the runaway Anthropocene.

\section{Rhythms, cycles, people and accelerated change - where are we?}

That small geoid the Earthlings call home - once just suspended dust in a small corner of the universe - is subject to a series of laws, 
movements and cycles. It makes regular orbits around its Sun, while also rotating on its own axis. It is now inhabited by more than 7 billion people on different continents and in different spheres or biomes. The strength and magnitude of the linkage between nature and human activity has been growing steadily, and the increasing complexity of associated phenomena only increases the demand for these to be better explained and anticipated, against the background of human ideas, decisions and actions certainly, but also chance events. We are accumulating more and more relevant data, and while these are the preserve of an ever-growing number of scientific disciplines seeking to study and understand all the relationships, geography may continue to regard itself as at the centre of all that.

The entire Earth system consists of fully dynamic conditions, with each process from plate movements planet-wide through to mass movements locally forming a natural part of theoverall whole. Dynamic processes in the atmosphere are a further natural part of change. Furthermore, many biological rhythms have taken shape in the course of evolution, as organisms have adapted to the cyclical events referred to. Humankind's dependence on nature, and on its cyclicity, would seem to be something obvious and taken as read. Indeed, our dependence on the natural environment made it necessary for the activity of our species to be adjusted in the same kind of way cyclically - in relation to both life and work (Zawilska \& Nowak, 2002). However, natural processes that have their cycles, and for which the full gamut of dependent relationships remain unknown, are beginning to be changed and accelerated by the presence and activity of Homo sapiens.

For so many of the processes ongoing on Earth are occurring on a scale not met with hitherto, with a strength or at a rate that is unprecedented. This is true of the concentration and growth of population, huge disparities between wealth and poverty, mobility, tourism and migration, the overall built-up area and the urbanisation that that often leads to. Society in the Western world has been associated with a high level of mobility for decades now (Kaufmann, 2016), but other regions are now catching up, seeing this as the very essence of modern life (as do Polish people for their part) (Więckowski, 2008). The organisation of large-scale events adds further to the desire - even the pressure - to transfer from one place to another, and the events involved are now organised in more and more far-flung parts of the world. Thus, UEFA's European Championships in football have fostered European integration by being transboundary (bilateral) affairs, while the 2020 version was even supposed to have been hosted by countries across the continent. In some context at least, this would have to be seen as excessive movement on the part of teams, staff, authorities, fans and others.

It is possible to view borders in this context, noting how they have come to reduce flows far less than they once did. That for example denotes abandonment and neglect of certain infrastructure - that "debordering"renders obsolete (Dołzbłasz \& Zelek; 2019, Furmankiewicz, Buryło, \& Dołzbłasz, 2020). But on the other hand we see a litter-strewn landscape, over-marking of territory (using too many signs and designations, boards informing about funds and rules of the road, and so on). Equally, the much-guarded borders of old were of course a mass of walls, ditches and other objects serving defensive purposes (Vallet, 2016).

Humankind's manifold large and small influences on the planet are now very welldocumented. And while the significance is certainly rising overall, this is also manifested in identifiable human cycles, be these economic, social or geopolitical - and this fact can serve to both speed up and slow down certain processes. There are many different concepts that regard age - or in fact membership of a defined generational group - as a key factor underpinning transformations in values. Generational change in connection with a change of social context gives rise to change regarding values (Kowalski, 
2019). In this context, each era looks specific, with our generational cycle entering a phase that looks "isolationist", given the migration crisis, Brexit, rising nationalism, populism and so on (Kowalski, 2016, 2019). There have long been those who have seen elements of repetition to all this, as successive cycles culminate in, say, the French Revolution and Napoleonic Wars, the revolutionary surges of the 1830s and 1840s, the events of the 1860 s and 1870s, the turbulence and wars of the early 20th century (notably World War I), then World War II, the great transformations of the 1980s, and the recently-observed increases in political tensions in various parts of the world (e.g. the Middle East, Ukraine, etc.), (Kowalski, 2016, 2019).

In all of that, resources are being consumed on a grand scale. Materials and objects are being used - and wastes being produced like never before in the history of our planet. Changes are now so vast, their traces so significant, that we have come to term this as if it was genuinely a new Epoch in that history - as the Anthropocene. And of course the changes can be noted both locally and globally, thanks to rising levels of $\mathrm{CO}_{2}$ and other greenhouse gases and the underpinning, ever-growing demand for energy for lighting, heating, the production of food, transport, and consumption in general.

\section{Earth's Anthropocene}

Obviously, with such huge numbers of people on the move until so recently there has to have been an impact on the natural and cultural environment. Indeed, more and more traces are being left by different human activity, ranging from the transformation of places (with permanent infrastructure, changed relief, modified flora and fauna, increases and changes in deposited garbage and waste), through the impact on climate (e.g. air pollution, carbon footprints people leave), to the consumption of resources, not only on the local scale. Terrestrial ecosystems have been affected, the atmosphere influenced, and activity capable of modifying the hydrological cycle engaged in. Environmental pollution, loss of natural areas, atmospheric pollution, pollution of the sea and oceans, and climate change are all cases in which humankind has managed to bring about change in Earth systems.

The concept of the Anthropocene has recently come to represent a substantial focus of critical discussion, not only in geology, but also in the social sciences (see e.g. Glikson, 2013; Castree, 2014a, 2014b; Braun, 2015; Cook, Rickards \& Rutherfurd, 2015; Lorimer, 2015; Moore 2015; Gren \& Huijbens, $2014,2016)$. The term used less formally has become popular, deployed in different scientific communities, including the humanities; as well as in the scientific literature, discussions and the public media. In essence, the Anthropocene is a proposed geological Epoch dating from the time that significant human impact began to be exerted on Earth's geology and ecosystems, including, but not limited to: global climate impacts due to carbon emissions and the shifting of more sediments than all rivers on Earth combined can manage (Crutzen, 2002, 2006; Rockstrom $\&$ Klum, 2012). The Epoch thus began as soon as there was any more significant human activity (Crutzen \& Stroemer, 2000; Crutzen, 2002), but the developed associated thesis basically holds that human influence has so come to dominate all non-human-induced processes that it is now (and will in the further future prove) potentially identifiable as a distinct layer in the geological record that would denote the transfer from the Holocene into a new Epoch with a pervasive human signature (Crutzen, 2002; Crutzen \& Stoermer, 2000).

The above assertions further reflect the fact that, despite a growing human impact on the Earth system during the Holocene as well, none of that Epoch's subdivisions are actually definable by reference to directly and clearly anthropogenic signals in the stratigraphy. This is not to dismiss changes then resulting from human activities entirely, as these were durable, tangible and potentially dateable. The difference rather lies 
in the way that they were usually gradual, heterogeneous across space and diachronous (Ruddiman 2013; Edgeworth et al., 2015; Edgeworth, Ellis, Gibbard, Neal, \& Ellis, 2019). For the Holocene - as an interglacial of relatively uniform climatic conditions - brought the expansion of humans, the development of agriculture, the growing use of metals, global mobility, and the depositing of the first wastes.

Above and beyond those influences, Lewis and Maslin (2015) hypothesised an onset for the Anthropocene dating back to around 1610 - paradoxically a date chosen as marking the low-point for a decrease in atmospheric $\mathrm{CO}_{2}$ measured in Arctic ice cores that lasted for around 100 years. That change in the atmosphere has come to be associated with the tragic deaths of over 50 million indigenous inhabitants of the Americas following their exposure to diseases carried there by Europeans in the 15th century. This nearannihilation of these indigenous populations was sufficient to cause a significant decline in farming and the setting of fires, with forest therefore able to regenerate and exert a further knock-on effect on atmospheric $\mathrm{CO}_{2}$ levels.

More familiarly, the Industrial Revolution, with its onset in the late 1700s in association with the ever-wider use of fossil fuels, has also been proposed as a base period for the Anthropocene (Crutzen \& Stoermer, 2000; Crutzen, 2002), though the more-marked and widespread transformation followed rather in the 19th century, with the impact on global atmospheric $\mathrm{CO}_{2}$ concentrations at first looking insignificant, as did the gradual ash-induced changes in lake sediments proceeding slowly over many decades (Wolfe et al., 2013; Snowball, Hounslow, \& Nilsson, 2014). Some therefore favour a more abrupt and far later tipping point into the Anthropocene complete with a potential stratigraphic marker. This is dated to 16 July 1945 and reflects the first test of the atomic bomb at Alamogordo, New Mexico (Zalasiewicz et al., 2015). The isotopic products of that bomb-testing do indeed provide a globally distinctive marker horizon in soils, ice cores, lake sediments and oceans. The only synchronous stratigraphic signal with a global range seems to be associated with the artificial radionuclide fallout from nuclear weapons testing, which covers a topsoil layer of up to tens of centimetres thick (Prokop, 2020).

A base for the Anthropocene close to the middle of the 20th century has its logical justifications, in that it also coincides with something called the Great Acceleration ( 1950) (Steffen, Crutzen, \& McNeill, 2007), simultaneously entailing a major expansion in the human population, large changes in natural processes, and the development from minerals of such novel materials as concrete and plastics (Waters \& Zalasiewicz, 2018; Zalasiewicz, Gabbott, \& Waters, 2019). As part of the Great Acceleration, this fossil fuel-propelled tour de geoforce of human activities, catalysed by science and technology, is seen as epitomised by international aviation, and related intimately to climate change (Gössling, Scott, Hall, Ceron, \& Dubois, 2011; Hares, Dickinson, \& Wilkes, 2010). Thus, seen through the prism of the Anthropocene, modern life is a geophysical force contributing to a reshaping of the Earth for human purposes, as well as climate change.

\section{Planetary self-regulation? What kind of lesson has one virus taught us?}

Every now and again, development on Earth is held back or slowed down by events both local and global, which may be natural disasters (e.g. involving meteorites, volcanic eruptions, floods, droughts and so on) or economic crises (like the Depression of the 1930s or the crash of 2008-2009), but also wars and epidemics. While the experiences of two World Wars sufficed to in some way limit the possibilities for further major armed conflicts, there is unfinished business in many parts of the world, proxy wars continue to break out, and the pressure to engage in an arms race is more or less constant. Longer-term conflicts, like that in Syria, influence the situation 
in other regions of the planet - from the points of view of the economy and society, and including through the phenomenon of migration. People take flight - as refugees - and we have a migration crisis in Europe, which is at the same time a political crisis. States like Hungary and Austria, but also Greece and Italy (which form the front line for contact with what are mostly seen as unwelcome guests) are beginning to try and fence themselves off, putting back borders that had been brought down (Vallet, 2016; Sobczyński, 2018; Kolosov \& Więckowski, 2018), and acting to justify the existence of barriers, barbed wire, walls, electronic blockades and controls (Vallet, 2016; Żelichowski, 2018). A famously analogous situation is that applying along the southern border of the United States.

And as terrorist attacks have appeared on a scale not met with hitherto - in what were thought to be cities at peace, like New York, Paris and Brussels, we have to concede that, while conflicts and wars have somehow been limited, they have not been eliminated.

And the same goes for epidemics or pandemics. Having lived through (most of) the 20th century, and almost two decades of the 21st, without these, we may have started to believe that they were a thing of the past - that something like the H1N1 'Spanish' flu of 1918-19 (in fact only just over a century ago) would not repeat. After all, that was a pandemic hitting hard on the back of a gigantic and terrible war, and the associated lack of sanitary conditions, and presence of both hunger and malnutrition. And yet it is generally recognised that the 20th century experienced two more pandemics after that, i.e. the 'Asian' flu (H2N2) of 1957, and the 'Hong Kong' flu of 1968.

While today's level of development of medicine and standard of living were to offer protection against subsequent pandemics, globalisation has seemed to increase the rate of occurrence. In truth, the 21st century has already experienced four pandemics: SARS in 2002, 'Bird flu' in 2009, MERS in 2012, and Ebola - which peaked in 2013-14. This actually-tangible increase in pandemic outbreaks post-2000 is believed to have strong links with factors of global change (Coker et al., 2011; Greger, 2007; Wu et al., 2017; Gössling et al., 2020). The main reasons cited for the increased pandemic threat in the 21st century are: a rapidly-growing and mobile world population, trends as regards urbanisation and the concentration of people, industrialised food production within global value chains, increased consumption of higher-order foods including meat, and, the development of global transport networks acting as vectors in the spread of pathogens (Pongsiri et al., 2009;

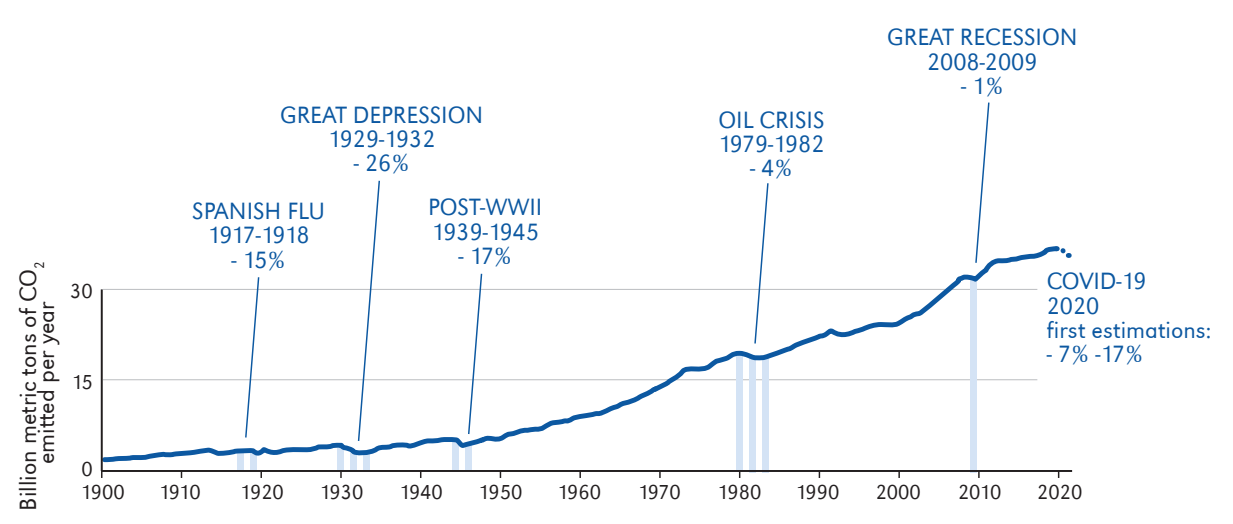

Figure 1. Global carbon emissions and the main recessions impacts

Source: Barone E., Tweeten L., Wilson Ch. \& Law T., (2020), Global Carbon Project, Carbon Dioxide Information Analysis Centre (CDIAC). 
Labonte, Mohindra, \& Schrecker, 2011; Gössling et al., 2020). Yet outbreaks of diseases such as SARS, Ebola, Marburg, hantavirus, Zika and avian influenza all share the further feature of having arisen out of anthropogenic impacts on wild ecosystems and biodiversity (Petersen et al., 2016; Schmidt, 2016; World Bank, 2012; Gössling et al., 2020). Figure 1 shows combined data of raising global $\mathrm{CO}_{2}$ emission with the moments of reduction due to some important events, including pandemics.

A new pneumonia of unknown cause detected in Wuhan, China, was first reported to the WHO Country Office thereon 31 December 2019. The resulting viral-induced pandemic of 2020 has put a stop to huge and rapid development, it becoming abundantly clear that - actually - pretty much anything can happen, quite suddenly, and have global consequences. One virus stopped the whole world for several weeks or even months, and the first response of individual countries was lockdown and global closure. This happened step by step, with this first being a matter of a few parts of Asia and the odd case elsewhere. But then the virus established a permanent presence in Italy - especially Lombardy and Piedmont, and numbers of cases began to rise dangerously in Europe and North America. 11th March saw the WHO declare this a pandemic of official status.

The real total number of cases remains unknown, as testing is limited in most countries. Although Europe had around two million confirmed cases of COVID-19 in midJuly 2020, by then the United States was at around 3.8 million confirmed cases, with India on 1.1 million cases and Brazil on 2 (WHO 2020). The total (cumulative) number of people diagnosed with COVID-19 reached 14.5 million worldwide in mid-July 2020, with $600,000+$ already dead from the disease (WHO 2020). As of 11 September 2020 (a half-year after the $\mathrm{WHO}$ pandemic declaration), more than 28.2 million cases have been reported worldwide, with 910,000+ people dead and more than 19 million have recovered (WHO, 2020, Roser et al., 2020) (Fig. 2).

\section{Changes and consequences at lightning-like speed}

Thus far, the COVID-19 pandemic event has caused a significant, though not total, collapse of the human-Earth system. This means that we are probably entering a phase of reorganisation, innovation and creativity essential for our human system to transform itself and adapt to the new context the planet we inhabit has provided (Lew, Cheer, Haywood, Brouder, \& Salazar, 2020). Many human activities have changed post-March 2020, and the short-term and long-term consequences are many and varied. With a view to those consequences - for further human activity on Earth, and for the Anthropocene - being better understood, it was decided to embark here upon a preliminary analysis of the specific aspects of borders, human freedoms, mobility and transport, as well as matters of work, habitation, rest and recreation.

\section{Borders, human freedoms and quarantine}

Following the declaration of an event of pandemic status by the WHO (on March 11th 2020), it emerged that most countries' governments were convinced closures of their own state borders represented the most effective protection against the spread of COVID-19. That went hand in hand with the restoration of border controls, the sealing of borders, or even their outright closure. First border closures, and even the isolation of whole regions, had actually taken place before March, though on by no means the same scale. But in response to the pandemic, many countries and regions also imposed quarantines, entry bans, or other restrictions for citizens of (or recent travellers to) the areas affected most severely. Other countries and regions imposed sweeping global restrictions applying equally to all foreign countries and territories, and also preventing their own citizens from travelling abroad. 

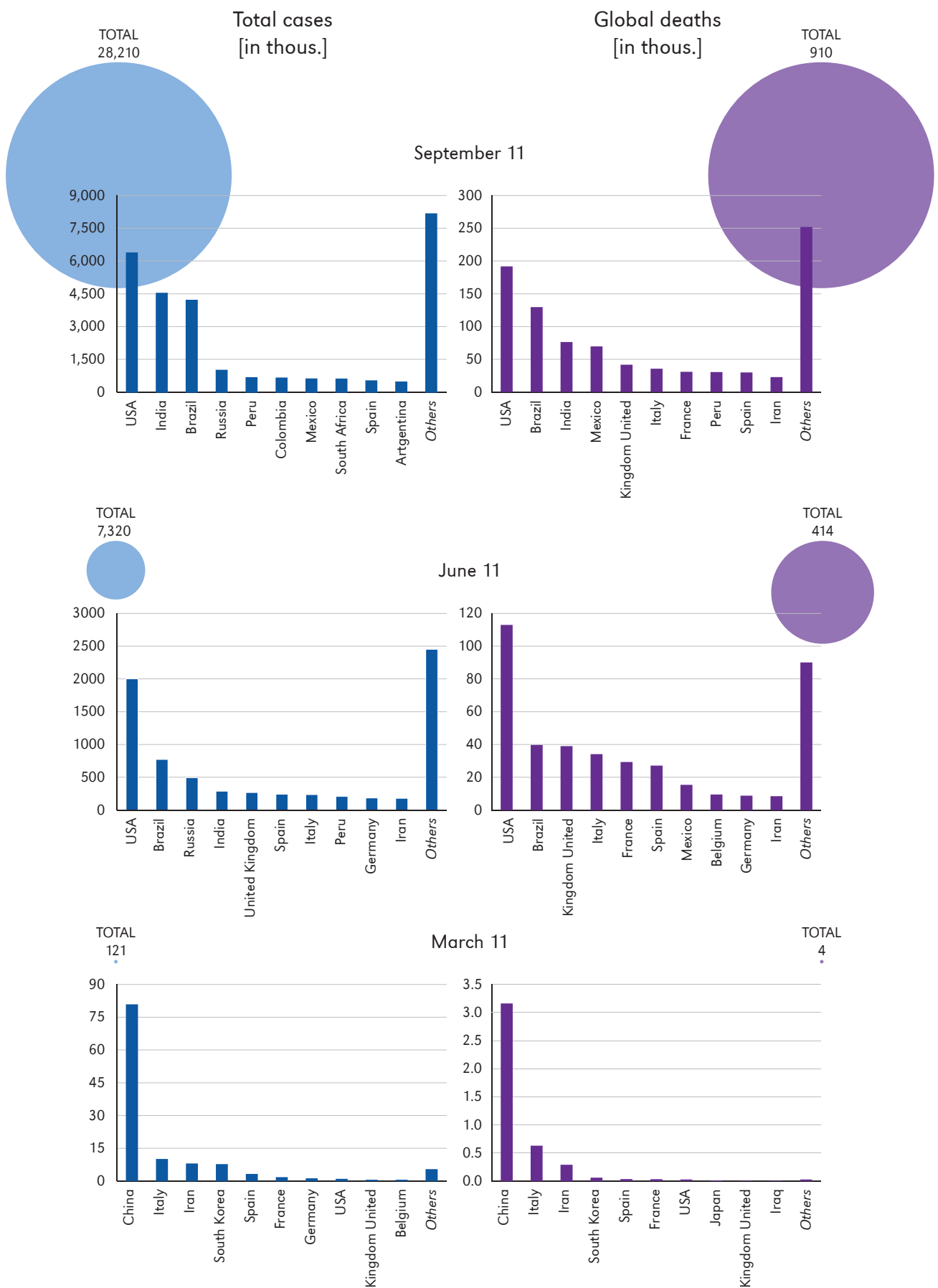

March 11

TOTAL

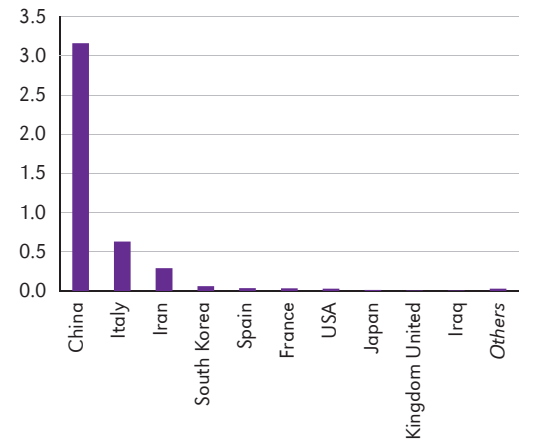

Figure2. The ten most affected countries by COVID-19: March 11th 2020, June 11th 2020 and September 11th 2020

Source: own work on data collected by Roser et al. 2020. 
However, decision-makers opted for different strategies for trying to cope with the pandemic that have already prompted analyses of various countries' institutional and governmental responses (Ruiu, 2020; Bryce, Ring, Ashby, \& Wardman, 2020; Nygren \& Olofsson, 2020; Sonn \& Lee, 2020; Kouřil \& Ferenčuhová, 2020). Kouřil and Ferenčuhová (2020) feel that three dominant strategies have been recognised and commented on, i.e. (1) regional, municipal or nationwide lockdowns (Ren, 2020); (2) a "soft governance approach" with reliance on individual responsibility, as in Sweden (Nygren \& Olofsson, 2020); and (3) a strategy of using ICT and surveillance technologies instead of resort to general containment (Sonn \& Lee, 2020; Kouřil \& Ferenčuhová, 2020).

Five types of regions in Europe were then identified in line with the impact of COVID-19 and related restrictions - from the type moderately impacted upon by COVID-19 (e.g. Sweden, Latvia and Hungary) to those impacted by the pandemic in a manner capable of being seen as substantial (Ireland, regions of Greece, Czechia, Norway and Switzerland), significant (e.g. regions of France, Belgium, Austria, Slovenia and Portugal), or extreme (Spain, Italy and France's Paris region), (Pászto, Burian, \& Macků, 2020).

The closure of borders was both sudden and rapid. There was a domino effect - with duplication of solutions from other countries; but almost always without much attempt to consider the consequences (for the given country itself or its neighbours). A few different possibilities were resorted to by regions and countries, e.g. closing one section of a border, one-sided closure, and closure (i.e. suspension) of one type of transport (e.g. rail or road). Thus, at the beginning of the pandemic, we observed the closure of borders with Italy; both-sided closure (literally or with the restoring of border controls at check-points); closures of borders of one type (e.g. between Schengen states); and the closing of all the borders of a given country.

It emerged soon enough that closures had major consequences, while the effectiveness of the measure had its limits. Problems with transit and with returns home arose immediately, problems with certain kinds of transport and with transboundary workers; of course problems with (an end brought to) tourism and the supply of goods. Many border zones around Europe experienced an immediate shortage of workers, and the lack of hitherto-normal opportunities to travel to the country next door to purchase certain goods and services. Border restrictions remained in place until June 2020, but a further aspect of interest related to a process of reopening that proved uneven, incomplete and selective - and as regards statistics, rates and directions relating to the pandemic's development in different countries (even distant ones), as well as the level of significance of tourism to the given economy.

\section{Mobility left in abeyance}

People's movement around the planet had recently attained such a scale that it had come to be known as hypermobility (Kaufmann, 2016). But tourism and mobility made at least a partial contribution to the spread of the virus, as people moved still-freely between countries and even continents. More specifically, certain tourist destinations are suspected of serving as seed-beds for the virus back in January and February (and partly also in March) 2020. The Alpine resort of Ischgl in Austria is for example alleged to have played this kind of role. Yet, while the mobility phenomenon seems assertive in the way it favours the spread of negative effects, it also proves sensitive or vulnerable - being one of the first areas to suffer when restrictions are introduced or tightened for whatever reason (Gössling et al., 2020). The sudden appearance of restrictions also showed the scale of the phenomenon that tourism represents, with millions even needing - with difficulty - to return home from different parts of the world. With international travel bans affecting over $90 \%$ of the world population and widespread restrictions on public gatherings and community mobility, tourism largely ceased in March 2020 (Gössling et al., 2020). 
The aforementioned return of people to their countries and cities from further afield involved special EU procedures (through EU Civil Protection Mechanism), in the case of over 92,000 people from which 82,000 citizens of the Union returning from beyond and needing assistance for that reason (European Commission 2020). More widely, some 600,000 people returning to Europe included 200,000 Germans and 160,000 French. More than 85,000 Americans sought to return to the USA (Goldstein, 2020). Individual countries launched their own innovations to bring hundreds of thousands back home. For example, in the period March 15 to April 15, the Polish flag carrier LOT made a limited return to operations as it flew over 54,000 people (not solely Poles) under the "LOT Do Domu" (LOT Flight Home) programme. The government of India implemented its plan to evacuate citizens from places around the world through the "Vande Bharat Mission" primarily run in May. However, in the March-June period as a whole more than 250,000 Indian citizens returned to their country.

Further impacts on movement were exerted as states countries responded more widely with their non-pharmaceutical interventions (NPIs), involving lockdown (home isolation, voluntary/mandatory quarantine), social distancing (of vulnerable or entire populations), closures of schools/universities and non-essential businesses/workplaces, cancelling or postponing of events (i.e. major conferences and trade fairs, concerts and festivals, political debates and elections, sports seasons and the Summer Olympics), and bans on gatherings of people above certain numbers (Gössling et al., 2020).

Political decisions thus influenced the rates at which mobility came to be limited, as well as the scale. International travel was the first to be confined, or in some cases stopped altogether. The local and regional means employed were varied, including: (a) isolation of people at home, under a total ban on exits (in circumstances of quarantine, certain regions and more widely in Italy); (b) isolation of people at home but with limited possibilities to leave for shopping purposes, with a pet or to engage in certain kinds of sporting activity (as in Paris); and (c) limitations on movements around a given country (e.g. no more than $100 \mathrm{~km}$ from home, or within a single county as in Slovakia or Italy). Specific kinds of prohibition also made their appearance, e.g. no entries into parks or on to beaches, and so on. Particular types of mobility were also prohibited, e.g. commutes to work or travel for the purposes of recreation. An even less-usual situation actually applied in many countries saw restrictions imposed during periods especially associated with movement, as at Easter or in the course of long weekends.

\section{Transport and the changes affecting it}

One of the lockdown's first consequences saw transport stopped, slowed down or otherwise limited. As early as in March 2020 there was a near-instant grounding of aircraft and introduction of relevant restrictions, lack of new flights, lack of any possibility to make reservations, and so on. The pandemic has therefore had a highly significant impact on the aviation industry, with travel restrictions imposed, and a slump of demand among travellers in any case. It is true to say that the first most severe and sudden "pulling of the plug" on airlines, airports and individual aircraft was followed by a widespread if limited resumption of services, albeit under special supervision. Nevertheless, as spring ended, many airlines had already filed for bankruptcy, with most cutting wages and beginning to lay off staff. British airline FlyBe was the first to succumb to market pressure, declaring itself bankrupt on 5 March 2020 (Business Insider, 2020). Major airlines, including Scandinavian Airlines (17 March 2020), Singapore Airlines (27 March 2020) and Virgin (30 March 2020), as well as tour operators including German TUI (27 March 2020) were quick to request tens of billions of dollars worth of state aid (Gössling et al., 2020). Significant reductions in passenger numbers led to planes flying empty between airports, and to the cancellation of flights (e.g. in Paris Orly airport 
the number of flight dropted in march from 600 flights and 90.000 passengers daily to respectively 20 flights and 1.000 passengers (mostly connections under programme of return home) (information obtained directly from the Orly airport in April 1st 2020).

IATA estimates that the 2020 financial losses will be of the order of $\$ 84.3 \mathrm{bn}$. A year later the anticipated level is $\$ 15.8 \mathrm{bn}$.

Maritime transport was the first form to run into difficulties, even though the reduction in flow was never so rapid or complete. Passengers on cruise ships might evaluate that differently, given the way one port after another refused entry, because the country involved was already coming down with the disease, or - more infamously - because cases on board had been reported and there was just no knowing how far that undesirable situation would proceed. Starting with the Diamond Princess as early as on 1 February 2020, at least 25 cruise ships already had confirmed COVID-19 infections by 26 March 2020 (Mallapaty, 2020). A cruise industry growing greatly in popularity before has therefore been a huge casualty of the downturn, with the share prices of the major lines down 70-80\% (The Economist, 2020).

Land transport was also much reduced and limited. European land links (e.g. into and out of Italy) were simply severed, irrespective of Schengen, while domestic connections were reduced and then also eliminated. The reasons behind it involved major restrictions on people's movements even within their own countries, as the need to "stay at home" became more and more pressing and obvious. Something had to substitute, and connections online and other new technologies boomed.

\section{Work-life}

Obviously the need for upkeep ensures the core status of work as a fundamental part of most people's activity. Yet the pandemic shook and left changed even this sphere of life. Unemployment rushed back, firms fell, orders were lacking or limited, and supply chains interrupted. While a first phase of change involved people's whereabouts being limited to home or place where work was actually engaged in, later on the partial and then total lockdowns set in. Remote working, teleworking, online working were engaged in wherever possible. Education (including higher education) moved online, as did the administering of the state. Concessions had to be made, with deadlines for final tax calculations and the paying of certain debts extended. What is more, the teleworking has remained in place through to the time of writing in a great many cases. Many world-class universities are already anticipating that the next academic year will see far-reaching limitations on real-world activity, with most or all taking place virtually. Certain specific professions go on booming, not least postal-delivery and courier services. And Poland for example saw many cases of restaurants repurposing to offer home deliveries, as domestic regulations confined their activities on the one hand, while people feared to frequent them in any case.

In March 2020, more than 10 million Americans lost their jobs and applied for government aid. The coronavirus outbreak could go on to take 47 million jobs in the United States, where the unemployment rate may hit 32\% - according to estimates by the Federal Reserve Bank of St. Louis. Nearly 900,000 workers lost their jobs in Spain once that country went into lockdown in mid-March 2020. During the second half of March and April, more than 11 million French workers applied for temporary unemployment benefits, while 1 million British workers joined the UK's Universal Credit scheme. By June, the wave of layoffs had reached Latin America, with several tens of millions of people out of work. In this way, as in others, this disease outbreak is a major destabilising threat to the global economy. Most likely the pandemic will provoke a crisis characterised by a lack of solidarity in society and the identification of increasing numbers of people who are now "redundant" in the worst sense of the term. The experiencing of hurt, lack of fairness and 
of course poverty are inevitable consequences further down the line.

Among all these huge changes, there are some that can serve to limit humankind's more negative impacts on the environment, in this way ushering in some kind of respite where the runaway Anthropocene is concerned. Several months of limited homework-home movement have already been experienced, and the importance of "nearby services" can only rise, with - for example shopping locally looking less like a possibility to be pursued with reluctance, and more of a clear necessity.

The aforementioned need or requirement for more time to be spent at the place of residence (in extremis on the basis of bans on leaving home and quarantine, but also because home has become the place in which we work and receive an education) means ever-greater importance being attached to the way in which we live and reside. How may a home in which we are potentially present 24/7 become a children's education centre, a home office, and a place to spend a weekend or even a holiday? Matters of residence in one's own place (potentially the only space in the world we can call our own) are brought to the fore very greatly by the present crisis. Yet loss of work and/or the collapse of finances may force people out of earlier places of residence, just as it simultaneously makes them commit to further adaptation work. A reduced mobility - potentially of a more permanent nature - has already ensued - but also been favoured - as homes undergo modification to function better and in a more multifaceted way.

\section{$R \& R$}

The above change has disrupted in an abrupt and brutal way the need (most likely always present in people) to take a break, get away, be somewhere different from normal. The United Nations World Tourism Organization estimated that global international tourist arrivals might decrease by $20-30 \%$ in 2020, leading to a potential loss of US $\$ 30$ $50 \mathrm{bn}$. In many of the world's cities, planned travel declined by $80-90 \%$. In principle, it was tourism that became the first victim of the pandemic, especially as a consequence of the parallel processes of border-closure, lockdown and quarantine, with tourist facilities simply closed en masse: whether in terms of places to visit, or places to spend time like hotels and restaurants, or tourist attractions (museums, castles, recreational areas and parks). The pandemic has already affected tourism greatly. This may be no bad thing, and does not have to come down to limitation and nothing more. COVID-19 may offer the impetus for individuals to transform their travel behaviour, even though a transformation of the tourism system overall would be extremely difficult to achieve.

The Northern Hemisphere summer holiday assumed the status of major challenge. On the one hand, people want and need to rest, to make use of pre-existing reservations and planned getaways; while on the other hand enterprises, localities, regions and states all want (or at least need) tourists to pay their visits. But first real-life assessments look even more serious than had been anticipated. Even between March and the end of June, the shortfalls in numbers of tourists were costing Spain around 15 billion euros. By autumn and especially into next year - we shall know who has failed to make it through the crisis, and why. Tourism that was in reality excessive (and often entirely out of control) had seemed like a given of our world that nothing could change, yet the pandemic left that old certainty looking wobbly to say the least, as dramatic drops in foreign tourism make clear.

Even if we no longer get to know the whole world, we will still need rest, and a change of everyday environment. Equally, there are strong business and political voices speaking for the economy (tourism included) to be opened back up again as soon as possible, in the hope of a return to "normal" - but with affected businesses actually likely to be in receipt of substantial government/taxpayer (financial) support without even necessarily having to do more to meet requirements on sustainability or climate-change 
mitigation (Harvey, 2020; Kaufman, 2020; Hall, Scott, \& Gössling, 2020).

However, a possible (desirable) degrowth of overtourism calls more for a voluntary, planned contraction than for the haphazard reaction the pandemic has forced upon us. We can shorten the commute to holiday destinations or weekend trips. We can appreciate the availability more. However, as any shortening of distances takes place, the further development of tourism may be affected significantly, with the new outcome locally being potential overcrowding.

\section{Discussion. Every crisis is also an opportunity and a chance for reflection}

Even the development of the COVID-19 pandemic as it has proceeded so far (in the first half-year) has been enough to hold back the runaway Anthropocene to at least some extent. This is important given the way that - by definition - this is an Epoch in which humanity's impact on nature has begun to blow back on us in unpredictable and disastrous ways. The great acceleration that defined the Anthropocene may have begun in 1945, but in 2020 we are facing the first crisis in which the blowback destabilises our entire economy (Tooze, 2020). It is perhaps not going too far to see this as some form of planetary attempt at restoring self-regulation. But what has happened would be neither as strong or as universal, had different states not decided to close their borders, shut their citizens up at home and accept that a generalised lockdown was necessary. The early phase of (re)action was characterised by chaos, isolationist tendencies and an immediate desire to see the significance of the nation state restored. We all reacquainted ourselves with the reality that those states and their borders are still in place, and still able to meet - at least in part - their time-honoured defensive, filtering, checking and controlling functions.

Nature benefited rather tangibly, rather rapidly. The condition of waters and the air was able to improve quickly, as in many cities in China from the outset, and later in the until-now murky canals of Venice (NASA 2020). In its first week under lockdown (16-20 March), the Paris agglomeration immediately experienced a 20-30\% improvement in air quality, with a more than $60 \%$ fall in emissions of oxides of nitrogen. In China, lockdowns and other measures resulted in a $25 \%$ decline in carbon emissions (Myllyvirta, 2020), and a 50\% reduction in emissions of NOx (Zhang et al., 2020), and in India in New Delhi concentrations of PM10 and PM2,5 have withessed maximum reduction (> 50\%) in comparison to the pre-lockdown phase (Mahato, Pal, \& Ghosh, 2020). One Earth Systems scientist estimated that that alone may have saved at least 77,000 lives over two months (Burke, 2020). A kind of renaissance for nature in National Parks was also to be noted, as was the increased presence of animals in urban areas. On the other hand, personal protection rather rapidly gave rise to a new plastic littering problem, due to masks, shields and gloves.

Many governments are now mandating or recommending social distancing (or "physical distancing" to slow the spread of disease by minimising close contact between individuals) in regions and even whole countries affected by the outbreak (PHE, 2020; Ward, 2020). Other methods include quarantines; travel restrictions; and the closing of schools, workplaces, stadiums, theatres, or shopping centres. New regulations combine with human behaviourarising spontaneously to give rise to social and physical distancing methods involving staying and working at home, the limitation of travel, the avoidance of crowded areas and the use of nocontact greetings. General self-isolation also means less courage to make journeys and move, and that will also bring significant change for all of us, but also for enclosed spaces in general, be these in public transport, cultural institutions (cinemas, theatres and so on), education or hotels. A practical outcome is that we are liable to see customarily face-to face activities move to virtual platforms, as users become more acclimatised 
to online interfaces for conducting business, delivering educational programming, and engaging in a widening range of social activities (Cohen, 2020). Even in the most affluent societies, financially motivated decisions are made every day that decide upon chances, and decisions at the level of the individual will play a crucial role.

Ultimately, in the post-COVID-19 Anthropocene, global environmental governance mechanisms will need to become coupled more tightly with individual responsibility if we are to have an ecologically and economically efficient path forward towards sustainable development (Ali, 2020).

This pandemic has ensured that the programme of policies dealing with the different aspects of global change characterising the Anthropocene has become even more important, whether what is involved is climate change, pollution of the air and water (which do not change even though policies are addressed at them specifically), or chronic diseases like diabetes and obesity, as well as other diseases of civilisation (including circulatory) whose recent explosion should be regarded as a pandemic in its own right. Many causes here relate closely to the system we use to feed ourselves via the globalisation and industrialisation of farming, food processing and distribution, as well as the Westernisation of diet. It ought to be the case that social justice (Jaros, 2017) and spatial justice now assume ever-greater significance.

We also need to reflect on matters of economy and the reduction of the carbon footprint, as well as the amount of waste and refuse our activities leave behind. While a zero-waste economy and life do not exist, a major reduction can still be looked for. We will need to find win-win opportunities for lifestyles with lower ecological impacts that still mitigate the health risks capable of triggering survivalist selfishness (Ali, 2020).

While the timeline of the climate emergency tends to be measured in years, Covid-19 circled the globe in a matter of weeks. And the shock goes deep. By calling into question our mastery over life and death, the disease shakes the psychological basis of our social and economic order. It poses fundamental questions about priorities; it upends the terms of debate. Neither in the 1930s nor after 2008 was there any question that getting people back to work was the right thing to do (Tooze, 2020). But can that be said of today?

On the other hand, there can be a genuine hope that, in the nearest future of several to $10+$ months at least, we may see:

- reduced mobility, including as regards unnecessary travel,

- decreased industrial output, with less manufacturing of things we do not need, or only purchased on a whim,

- greater care for the daily environment in which we live our lives (with some reevaluation of quality of life),

- remote working and distance learning (in the absence of actual mobility),

- the further digitisation of the world in general, as well as its activities and services,

- rising significance for closed cycling in the economy,

- current environmental indicators in some fields that seem to be improving, as result of more-confined patterns of human activity in the circumstances of the pandemic.

\section{Final remarks. Covid-19 and its effects offer a chance to reduce humanity's influence on the Anthropocene process it set in train}

It could scarcely have been presumed that Earthlings might be brought to a sudden stop, even if it was possible to envisage a slowing of pace as regards development, life and mobility. For a single sudden event could scarcely be expected to generate very profound change, even if it could yield more reflective moods and decisions taken courageously and with more comprehensive consequences taken account of. Geography deals more and more with the supply of knowledge essential in diagnosing, planning and managing 
the planet and its resources. Explanations for emerging dependent relationships are offered, and the consequences of decisions and events made more clear.

For now at least, the measures seeking to combat the pandemic have not been revealing the strength of international and inter-personal assistance, or the fact that this is essential and effective. Equally, it is true that solidarity (a word significant for and well-known to Poles) has emerged as necessary and effective on the local scale. And this would appear to be one of the more important lessons we have learned - that local aspects can now be comprehended and recognised in line with their true worth.

Other positive impacts on the environment include governance-system-controlled investments towards a sustainable energy transition, and other goals related to environmental protection such as the European Union's seven-year, 1-trillion-euro budget proposal and 750-billion-euro recovery plan called "Next Generation EU", which seeks to reserve $25 \%$ of EU spending for climatefriendly expenditure (Carpenter, 2020; European Commission, 2020).

The worldwide disruption caused by the pandemic has unleashed numerous impacts on the environment, the climate, the economy and social life. The role of climate change and habitat loss in the prevalence of zoonotic disease is a complex issue that merits greater care over policy formulation being taken (Ali, 2020). "It is hard to ignore the nightly news bulletins and their repetition of cricket score-like statistics, the feeling of being overwhelmed by some foreign force. This is inevitably underscored by universal attempts to balance human and economic health. It is in this balancing act - where human health is tallied against economics - that the nub of our Anthropocene dilemma is revealed" (Massy, 2020). It can also be expected that a situation of global recession (possibly depression) will see austerity-prompted calls for the abandonment of existing attempts to introduce even modest carbon-pricing (Gössling et al., 2020).
With a view to encouraging reflection on humankind's potentially reduced impact on the planet, it is possible to come forward with the following few suggested priority areas of study:

- the issue of reducing mobility-related transport, especially by air and in particular as regards short-term travel over long distances;

- better planning - with any subsidies offered at the very least attached to requirements that more-sustainable (social and environmental) practices be invested in, as others have proposed;

- better use of resources, allocated in a morejust way, and used more sparingly,

- strong disincentives for non-essential and very short-term travel, with a consequently increased role for trips and recreation enjoyed in the vicinity of the place of residence (as also associated with an improved quality of everyday life);

- social and spatial justice: solidarity, assistance, adaptation and the increased significance of the local.

We could remember that life is for sharing, and that we are obliged to reduce our negative impact on the environment, and thus prepare the Earth for the generations to come as effectively as we possibly can.

Natural disasters affecting human life cause economic losses and social problems. Time will tell whether the COVID pandemic will change human activity; and if this is to represent a temporary fad, a short-term opportunity to change habits, or a morepermanent trend. In this respect, pandemics and their role in the Anthropocene represent subject-matter, not only for geography, but also for every socio-economic discipline. For geographers this will be an important field of study in the near future, and geographers will in fact find it impossible to stay away from this process.

Editors' note:

Unless otherwise stated, the sources of tables and figures are the authors', on the basis of their own research. 


\section{References}

Ali, S. (2020). How the current coronavirus pandemic links to questions of ecological sustainability in the Anthropocene. Springer Nature. Sustainability community, 8 April 2020. Retrieved from https://sustainabilitycommunity.springernature.com/posts/63681-how-the-current-pandemic-links-tobroader-questions-of-sustainability-in-the-anthropocene

Barone, E., Tweeten, L., Wilson, Ch., Law, T. (2020). The coronavirus pandemic has caused carbon emissions to drop. But that likely won't last. Time, July 9 2020. Retrieved from https://time.com/5864374/coronavirus-carbon-emissions/ [11 September 2020].

Braun, B. (2015). From critique to experiment: Rethinking political ecology for the Anthropocene. In T. Perrault, G. Bridge, J. McCarthy (Eds.), The Routledge handbook of political ecology (pp. 102-115). New York: Routledge.

Bryce, C., Ring, P., Ashby, S., Wardman, J.K. (2020). Resilience in the face of uncertainty: Early lessons from the COVID-19 pandemic. Journal of Risk Research, 1-8. https://doi.org/10.1080/13669877.2020.1756379.

Burke, M. (2020), COVID-19 reduces economic activity, which reduces pollution, which saves lives. Global Food, Environment and Economic Dynamics. Retrieved from http://www.g-feed.com/2020/03/covid-19-reduces-economic-activity.html [16 May 2020].

Carpenter, S. (2020). As Europe unveils 'green' recovery package, trans-Atlantic rift on climate policy widens. Forbes, 27 May 2020. Retrieved from https://www.forbes.com/sites/scottcarpenter/2020/05/27/ as-europe-unveils-green-recovery-package-trans-atlantic-rift-on-climate-policy-widens/\#6f2718c367e3 [4 June 2020].

Castree, N. (2014a). The anthropocene and geography I: The back story. Geography Compass, 8(7), 436-449. https://doi.org/10.1111/gec3.12141

Castree, N. (2014b). Making sense of nature: Representation, politics and democracy. London: Routledge. https://doi.org/10.1080/2325548X.2014.919148

Cohen, M.J. (2020). Does the COVID-19 outbreak mark the onset of a sustainable consumption transition? Sustainability: Science, Practice and Policy, 16(1), 1-3, https://doi.org/10.1080/15487733.2020.17 40472

Coker, R.J., Hunter, B.M., Rudge, J.W., Liverani, M., Hanvoravongchai, P. (2011). Emerging infectious diseases in southeast Asia: regional challenges to control. The Lancet, 377(9765), 599-609. https://doi.org/10.1016/S0140-6736(10)62004-1

Cook, B., Rickards, L., Rutherfurd, I. (2015). Geographies of the Anthropocene. Geographical Research. https://doi.org/10.1111/1745-5871.12127

Crutzen, P.J. (2002). Geology of mankind. Nature, 415(23). https://doi.org/10.1038/415023a

Crutzen, P.J. (2006). The Anthropocene. In E. Ehlers, T. Krafft (Eds.), Earth system science in the Anthropocene: Emerging issues and problems (pp. 13-19). Berlin: Springer.

Crutzen, P.J,. Stoermer, E.F. (2000). The "Anthropocene". Global Change Newsletter, 41, 17-18. https://doi.org/10.1007/3-540-26590-2_3

Dołzbłasz, S., Zelek, K. (2019). Wybrane cechy zagospodarowania przestrzennego i aktywności gospodarczej w otoczeniu miejsc przekraczania granicy polsko-niemieckiej. Przeglad Geograficzny, 91(4), 487-510. https://doi.org/10.7163/PrzG.2019.4.3

Edgeworth, M., de Richter, D., Waters, C., Haff, P., Neal, C., Price, S.J. (2015). Diachronous beginnings of the Anthropocene: The lower bounding surface of anthropogenic deposits. The Anthropocene Review, 2(1), 33-58. https://doi.org/10.1177/2053019614565394

Edgeworth, M., Ellis, E.C., Gibbard, P., Neal, C., Ellis, M. (2019). The chronostratigraphic method is unsuitable for determining the start of the Anthropocene. Progress in Physical Geography: Earth and Environment, 43(3), 334-344. https://doi.org/10.1177/0309133319831673 
European Commission. (2020). Overview of repatriation flights. Retrieved from https://ec.europa.eu/info/sites/info/files/20200910_coronovirusoutbreak_euresponse_repatriation.pdf [11 September 2020].

European Commission. (2020). Europe's moment: Repair and prepare for the next generation. Retrieved from https://ec.europa.eu/commission/presscorner/detail/en/ip_20_940 [4 June 2020].

Furmankiewicz, M., Buryło, K., Dołzbłasz, S. (2020). From service areas to empty transport corridors? The impact of border openings on service and retail facilities at Polish-Czech border crossings, Moravian Geographical Reports, 28(2), 136-151. https://doi.org/10.2478/mgr-2020-0011

Glikson, A. (2013). Fire and human evolution: The deep-time blueprints of the Anthropocene. Anthropocene, 3, 89-92. https://doi.org/10.1016/j.ancene.2014.02.002

Global Carbon Project, Carbon Dioxide Information Analysis Centre. (CDIAC). Retrieved from https://cdiac.ess-dive.lbl.gov/trends/emis/meth_reg.html [15 September 2020].

Goldstein, M. (2020). US State Department brings home more than 85,000 Americans in Coronavirus crisis. Forbes. Retrieved from https://www.forbes.com/sites/michaelgoldstein/2020/04/10/us-statedepartment-brings-home-more-than-50000-americans-in-coronavirus-crisis/ [11 September 2020].

Gössling, S., Scott, D., Hall, C.M., Ceron, J.-P., Dubois, G. (2011). Consumer behaviour and demand response of tourist to climate change. Annals of Tourism Research, 39(1), 36-58. https://doi.org/10.1016/j.annals.2011.11.002

Gössling, S., Scott, D.T., Hall, C.M. (2020). Pandemics, tourism and global change: A rapid assessment of COVID-19. Journal of Sustainable Tourism, 1-20. https://doi.org/10.1080/09669582.2020.1758708

Greger, M. (2007). The human/animal interface: Emergence and resurgence of zoonotic infectious diseases. Critical Reviews in Microbiology, 33(4), 243-299. https://doi.org/10.1080/10408410701647594

Gren, M., Huijbens, E.H. (2014). Tourism and the Anthropocene, Scandinavian Journal of Hospitality and Tourism. https://doi.org/10.1080/15022250.2014.886100

Gren, M., Huijbens, E.H. (Eds.). (2016). Tourism and the Anthropocene. London: Routledge. https://doi.org/10.4324/9781315747361

Hall, M.C., Scott, D., Gössling, S. (2020). Pandemics, transformations and tourism: Be careful what you wish for. Tourism Geographies, 22(3). https://doi.org/10.1080/14616688.2020.1759131

Hares, A., Dickinson, J., Wilkes, K. (2010). Climate change and the air travel decisions of UK tourists. Journal of Transport Geography, 18(3), 466-473. https://doi.org/10.1016/j.jtrangeo.2009.06.018

Harvey, F. (2020, April 1). Financial help for airlines 'should come with strict climate conditions. The Guardian. Retrieved from https://www.theguardian.com/environment/2020/apr/01/financial-helpfor-airlines-should-come-with-strict-climate-conditions

IGC (2020). Retrieved from https://www.igc2020.org/en/ [11 September 2020].

Jaros, V. (2017). Social and transport exclusion. Geographia Polonica, 90(3), 247-263. https://doi.org/10.7163/GPol.0099

Kaufmann, A. (2016). Re-thinking mobility. London: Taylor and Francis. https://doi.org/10.4324/9781315244303

Kaufman, A.C. (2020). If we bail out airlines, it better come with climate rules. National Observer, 24 March 2020. Retrieved from https://www.nationalobserver.com/2020/03/24/news/if-we-bail-out-airlines-it-better-come-climate-rules

Kolosov, V., Więckowski, M. (2018). Border changes in Central and Eastern Europe: An introduction. Geographia Polonica, 91(1), 5-16. https://doi.org/10.7163/GPol.0106

Kouřil, P., Ferenčuhová, S. (2020). "Smart" quarantine and "blanket" quarantine: The Czech response to the COVID-19 pandemic. Eurasian Geography and Economics. https://doi.org/10.1080/15387216.2020.1783338

Kowalski, M. (2016). Cykle pokoleniowe w czasie i przestrzeni. Przeglad Geograficzny, 88(4), 489-510. https://doi.org/ 10.7163/PrzG.2016.4.4 
Kowalski, M. (2019). Generational cycles and changes in time and space. Geographia Polonica, 92(3), 253-273. https://doi.org/10.7163/GPol.0148

Labonte, R., Mohindra, K., Schrecker, T. (2011). The growing impact of globalization for health and public health practice. Annual Review of Public Health, 32(1), 263-283.

https://doi.org/10.1146/annurev-publhealth-031210-101225

Lew, A.A., Cheer, J.M., Haywood, M., Brouder, P. Salazar, N.B. (2020). Visions of travel and tourism after the global COVID-19 transformation of 2020. Tourism Geographies, 22(3), 455-466.

https://doi.org/10.1080/14616688.2020.1770326

Lewis, S.L., Maslin, M.A. (2015). Defining the anthropocene. Nature, 519(7542), 171-180. https://doi.org/10.1038/nature14258

Lorimer, J. (2015). Wildlife in the Anthropocene: Conservation after nature. Minneapolis: University of Minnesota Press. https://doi.org/10.5749/minnesota/9780816681075.001.0001

Mahato, S., Pal, S., Ghosh, K. (2020). Effect of lockdown amid COVID-19 pandemic on air quality of the megacity Delhi, India. Science of The Total Environment, 730. https://doi.org/10.1016/j.scitotenv.2020.139086

Mallapaty, S. (2020). What the cruise-ship outbreaks reveal about COVID-19. Nature, 580(7801), 18. https://doi.org/10.1038/d41586-020-00885-w

Massy, Ch. (2020). COVID-19, the Anthropocene, and transformative change. Agriculture and Human Values, 37(3), 551-552. https://doi.org/10.1007/s10460-020-10080-2

Myllyvirta, L. (2020). Analysis: Coronavirus has temporarily reduced China's CO2 emissions by a quarter. CarbonBrief. 2020.

NASA 2020. Retrieved from https://earthobservatory.nasa.gov/images/146362/airborne-nitrogen-dioxide-plummets-over-china [10 July 2020].

Nygren, K.G., Olofsson, A. (2020). Managing the Covid-19 pandemic through individual responsibility: The consequences of a world risk society and enhanced ethopolitics. Journal of Risk Research. https://doi.org/10.1080/13669877.2020.1756382

Moore, A. (2015). Anthropocene anthropology: Reconceptualizing contemporary global change. Journal of the Royal Anthropological Institute, 22(1), 27-46. https://doi.org/10.1111/1467-9655.12332.

Pászto, V., Burian, J., Macků, K. (2020). COVID-19 data sources: Evaluation of map applications and analysis of behaviour changes in Europe's population. Geografie, 125(2), 171-209. https://doi.org/10.37040/geografie2020125020171

Petersen, E., Wilson, M.E., Touch, S., McCloskey, B., Mwaba, P., Bates, M., Dar, O., Mattes, F., Kidd, M., Ippolito, G., Azhar, E.I., Zumla, A. (2016). Rapid spread of Zika virus in the Americas - implications for public health preparedness for mass gatherings at the 2016 Brazil Olympic Games. International Journal of Infectious Diseases, 44, 11-15. https://doi.org/10.1016/j.ijid.2016.02.001

Pongsiri, M.J., Roman, J., Ezenwa, V.O., Goldberg, T.L., Koren, H.S., Newbold, S.C., Ostfeld, R.S., Pattanayak, S.K., Salkeld, D.J. (2009). Biodiversity loss affects global disease ecology. BioScience, 59(11), 945-954. https://doi.org/10.1525/bio.2009.59.11.6

Prokop, P. (2020). Where the Meghalayan meets the Anthropocene: Stratigraphic signals of human-environmental interactions on the periphery of Indian civilization, Geographia Polonica, 93(4), 505-524. https://doi.org/10.7163/GPol.0185

Public Health England (2020). Coronavirus (COVID-19): What is social distancing? 4th March 2020. Retrieved from https://publichealthmatters.blog.gov.uk/2020/03/04/coronavirus-covid-19-what-is-social-distancing/ [30 June 2020].

Ren, X. (2020). Pandemic and lockdown: A territorial approach to COVID-19 in China, Italy and the United States. Eurasian Geography and Economics 1-12.

https://doi.org/10.1080/15387216.2020.1762103. 
Rockstrom, J., Klum, M. (2012). The human quest - Prospering within planetary boundaries. Stockholm: Bokforlaget Langenskiold.

Roser, M., Ritchie, H., Ortiz-Ospina, E., Hasell, J. (2020). Coronavirus Pandemic (COVID-19). Published online at OurWorldlnData.org. Retrieved from https://ourworldindata.org/coronavirus

Ruddiman, W.F. (2013). The anthropocene. Annual Review of Earth and Planetary Sciences, 41, 45-68. https://doi.org/10.1146/annurev-earth-050212-123944

Ruiu, M.L. (2020). Mismanagement of Covid-19: Lessons learned from Italy. Journal of Risk Research, 1-14. https://doi.org/10.1080/13669877.2020.1758755

Schmidt, C.W. (2016). Zika in the United States: How are we preparing? Environmental Health Perspectives, 124(9), A157-A165. https://doi.org/10.1289/ehp.124-a157

Snowball, I., Hounslow, M.W., Nilsson, A. (2014). Geomagnetic and mineral magnetic characterization of the Anthropocene. Geological Society, London, Special Publications, 395(1), 119-141. https://doi.org/10.1144/SP395.13

Sobczyński, M. (2018). Polityczne, ekonomiczne i społeczne przyczyny napływu uchodźców do Europy oraz główne szlaki migracyjne. In R. Żelichowski (Ed.), Droga usiana drutami. Imigrancka odyseja do Europy. Warszawa: ISP PAN.

Steffen, W., Crutzen, P.J., McNeill, J.R. (2007). The Anthropocene: are humans now overwhelming the great forces of nature. Ambio, 36(8), 614-621.

https://doi.org/10.1579/0044-7447(2007)36[614:taahno]2.0.co;2

The Economist. (2020). The coronavirus may sink the cruise-ship business. The Economist, 31 March 2020. Retrieved from

https://www.economist.com/business/2020/03/31/the-coronavirus-may-sink-the-cruise-ship-business [7 April 2020].

Tooze, A. (2020). We are living through the first economic crisis of the Anthropocene. The Guardian, 7 May 2020. Retrieved from https://www.theguardian.com/books/2020/may/07/we-are-living-throughthe-first-economic-crisis-of-the-anthropocene

Waters, C.N., Zalasiewicz, J. (2018). Concrete: The most abundant novel rock type of the Anthropocene. In D.A. Dellasala, M.I. Goldstein (Eds.), Encyclopedia of the Anthropocene. Vol. 1 (pp. 75-85). Oxford: Elsevier.

Ward, A. (2020). Has Sweden found the best response to the coronavirus? Its death rate suggests it hasn't. Vox, 28 April 2020. Retrieved from https://www.vox.com/2020/4/28/21240381/coronavirus-sweden-death-rate-cases-new-york [30 May 2020].

Więckowski, M. (2008). New international mobility of Poles. Espace, Populations, Societes, 2, 261-270. https://doi.org/10.4000/eps.2509

WHO (2020): Coronavirus disease 2019 (COVID-19) Situation Report 120. Retrieved from https://www.who.int/emergencies/diseases/novel-coronavirus-2019/situation-reports [20 July 2020].

Wolfe, A.P., Hobbs, W.O., Birks, H.H., Briner, J.P., Holmgren, S.U., Ingólfsson, Ó., ... Vinebrooke, R.D. (2013). Stratigraphic expressions of the Holocene-Anthropocene transition revealed in sediments from remote lakes. Earth-Science Reviews, 116, 17-34. https://doi.org/10.1016/j.earscirev.2012.11.001

Won Sonn, J., Lee, J.K. (2020). The smart city as timespace cartographer in COVID-19 control: The South Korean strategy and democratic control of surveillance technology. Eurasian Geography and Economics, 1-11. https://doi.org/10.1080/15387216.2020.1768423

World Bank. (2012). People, pathogens and our planet: Volume 2 - the economics of One Health.

Wu, T., Perrings, C., Kinzig, A., Collins, J.P., Minteer, B.A., Daszak, P. (2017). Economic growth, urbanization, globalization, and the risks of emerging infectious diseases in China: a review. Ambio, 46(1), 18-29. https://doi.org/10.1007/s13280-016-0809-2

Vallet, E. (Ed.). (2016). Borders, fences and walls. state of insecurity. London - New York: Routledge. https://doi.org/10.4324/9781315569758 
Zalasiewicz, J., Waters, C.N., Williams, M., Barnosky, A.D., Cearreta, A., Crutzen, P., ... Haff, P.K. (2015). When did the Anthropocene begin? A mid-twentieth century boundary level is stratigraphically optimal. Quaternary International, 383, 196-203. http://dx.doi.org/10.1016/j.quaint.2014.11.045

Zalasiewicz, J., Gabbott, S., Waters, C.N. (2019). Plastic waste: How plastics have become part of the Earth's geological cycle. In Waste (pp. 443-452). Academic Press. https://doi.org/10.1016/b978-0-12-815060-3.00023-2

Zawilska, J.B., Nowak, J.Z. (2002). Rytmika okołodobowa i zegar biologiczny. Sen, 2(4), 127-136.

Zhang, R., Zhang, Y., Lin, H., Feng, X., Fu, T.M., Wang, Y. (2020). NOx emission reduction and recovery during COVID-19 in East China. Atmosphere, 11(4), 433. https://doi.org/10.3390/atmos11040433

Żelichowski, R. (2018). Od kultury powitania do kultury odrzucenia - dwie strony tej samej imigranckiej monety. In R. Żelichowski (Ed.), Droga usiana drutami: Imigrancka odyseja do Europy (pp. 55-96). Warszawa: Instytut Studiów Politycznych Polskiej Akademii Nauk. 